\title{
建物劣化診断・整備提案 A DEVELOPMENT OF BUILDING システムの開発 MAINTENANCE SYSTEM
}

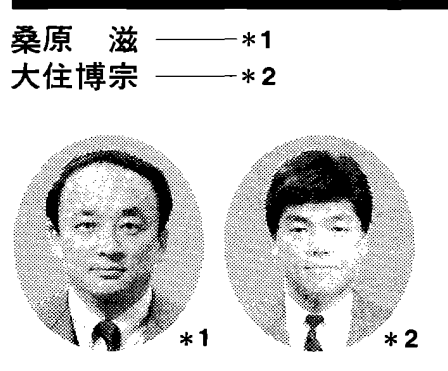

Shigeru KUWABARA

Hirosu OHSUMI

To provide facility management service, the Building Maintenance Planning System, a comprehensive expert system supporting inspection and diagnosis of building elements, rehabilitation planning and proposal had been developed and is being introducing. By using the system, current deterioration level and deterioration projection of inspected building elements are diagnosed and appropriate renovation specification are selected automatically. And finally, a rehabilitation proposal with renovation cost and performance recovory information is prepared for building managers. The concept and main structure of the system are based on accumulated results of research and development in building maintemance area conducted in NTT for last forty years.

Keywords :

maintenance, deterioration, diagnosis, renovation, facility management

\section{1 はじめに}

建築維持保全の技術テーマは，これを利用する組織の経営課題， 建築資産の所有形態, 維持保全を実施する部門の位置付け等に大き く影響されるため, 開発された技術の理解にはその背景や位置付け を理解することが重要である。電気通信用建物のための建築維持保 全関連の研究開発も社会・技術, 経営的ニーズによりいくつかの変 遷を経てきている。本報告では, 建築維持保全技術の研究開発とそ の背景の変遷を概観し，この間の技術的蓄積を総合化して開発され た「建物劣化診断・整備提案システム」の概要, 導入結果等を報告 する。

\section{2 電気通信用建物のための維持保全研究開発の变遷}

電気通信用建物のための維持保全に関する技術開発は, 組織の経 営課題やこれを実施する部門の位置付けにより次の 3 つの時期に分 けて捉えることができる。

第 1 期：公社としての発足時から 1970 年代中期まで

第 2 期：1970 年代後期から民営化まで

第 3 期：民営化から今日まで

第 1 期は，電話利用希望者の要望に応えるべき掲げられた「積滞 解消, 即時通話」の経営目標に基づく電気通信用建物の大量建設の 時期であった。建築維持保全領域では電気通信用建物の性能確保の ための資料整備と, 建設された建物や建築部材の耐久性調査に重点 をおいた研究開発が行われた。一例を図 1 に示す。

第 2 期は, INS の構築とこれに向けた経営基盤の確立が経営課題 とされた時期であり，建築的には新築物件の減少とともに，大量の 電気通信用建物の建設が一段落し, これらの建設ストックの経年劣
な業務となる建設ストックの維持保全の経済化が技術テーマとして 注目され，建築維持保全実施体制の強化による予防保全への移行と 建物診断技術・建物改修技術の開発に重点が置かれた。一例を表 1 に示す。

第 3 期では, 日本電信電話公社の民営化に伴い, 建物経営の地域 分権化が進んだ。さらにそれまで公社内部の建築組織が行っていた 建築関連業務の多くを社外で分担実施する会社が分離発足し, 建物 経営と建物の計画・設計・維持管理・技術開発業務の分離が明確化 された。建築維持保全業務の分担会社への移行に伴い, 建築維持保 全領域ではファシリティマネジメント（以下，FM と表現）の発想 に立った現状把握とデー夕蓄積, 経営判断を支援するための建物整 備計画作成と提案の効率的実施に力が注がれている。

\section{FM としての建物維持保全}

$\mathrm{FM}$ を「組織体の全施設及び環境を経営的視点から総合的に企 画・管理・活用する経営管理活動」（FM 推進連絡協議会による定義） とすれば，電気通信サービスの中期経営計画に基づき, 電気通信ネ ットワークの拠点としての電気通信用建物の建設・運営維持管理を 実施してきた建築関連業務は FM そのものであったといえる。

電気通信サービスをあまねく国内に提供するため, NTT は約 4 400 万 $\mathrm{m}^{2}$ の土地と約 2100 万 $\mathrm{m}^{2}$ の通信用建物を所有しており，建 設からの平均経過年数が約 25 年となるこれらの建物を事業展開に 対応して有効利活用寸ることが要望されている。ストックされた電 気通信用建物を中心基盤とし, 将来の電気通信技術の変化に対応し つつ高度な電気通信サービスの提供を支援するため, 図 2 に整理さ れる業務が，「通信の信頼性向上」「土地・建物からなるファシリテ

\footnotetext{
*1 (株)NTT ファシリティーズ研究開発部

*2 (株)NTT ファシリティース研究開発部
} 


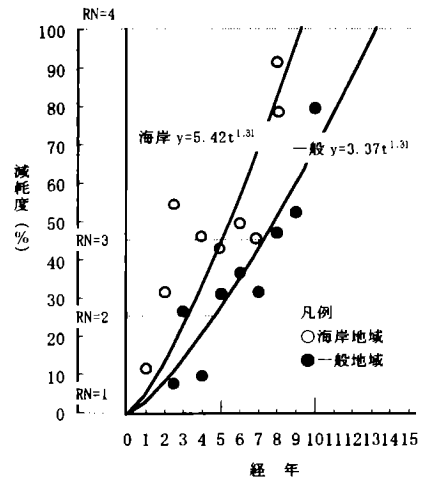

図 1 鉄部塗装の減耗度調査結果

表 1 修繥周期・修繥率表

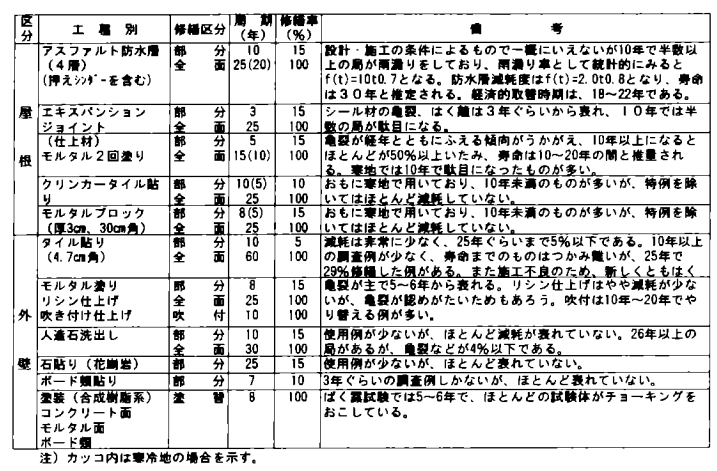

イの有効活用」「建物関連コストのミニマム化」を目的として提供さ れている(図3)。

建築維持保全は図 2 亿示す業務の中で「信頼性向上・老朽更新」 業務に相当するが，この業務は電気通信用建物のライフサイクルコ スト検討では図 4 に示すようにその $35 \%$ に関連することが分析さ れており，経営へのインパクトも大きい。ライフサイクルコストの 低減を図りながら，建物の信頼性を確保し，効率的に運用するため には，建物現状を客観的に把握したデー夕の整備と計画に基づいた 業務実施が必要とされる。さらに，「信頼性向上·老朽更新」への投 資に関する意思決定が建築技術知識の少ない建物経営者によりなさ れるため, 適切な時期に適切な方法で建物整備が行われるよう, 専 門技術的な内容を理解しやすい形でまとめた建物整備計画提案を行 う必要がある。

\section{4 建物劣化診断・整備提案システムの開発}

本システムは上記 “研究開発の変遷” の第 2 期後半に開発が行わ れた。開発のニーズとしては以下の 3 項目に整理される。

(1) 建物の劣化診断や整備計画の作成は, 専門知識とともに実務経 験が必要とされるが，組織としては担当者のスキルの多真に影響 されることなく，一定のレべルを確保した劣化診断や整備計画作 成が要望された。

(2) 建物の少化診断や整備方法の検討, 整備コストの算出には多く の稼働が必要とされる。時機を得た整備提案を行うためには効率 的な業務実施が要求された。

(3) 建築技術知識の少ない建物経営者が建物の劣化を理解し, 整備 時期・整㣁投資の適否について的確な判断を行うための判りやす

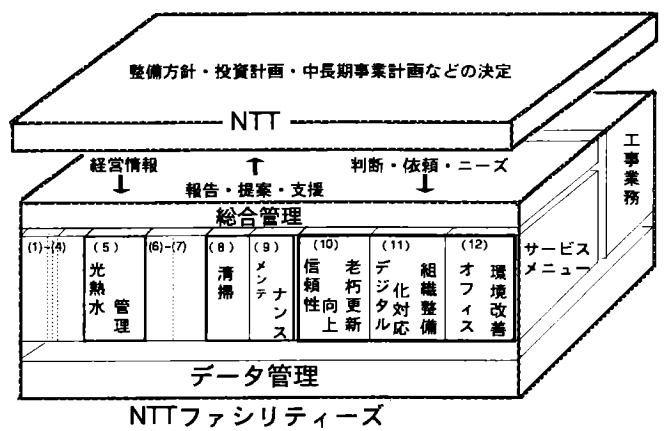

図 2 FM 業務の構成

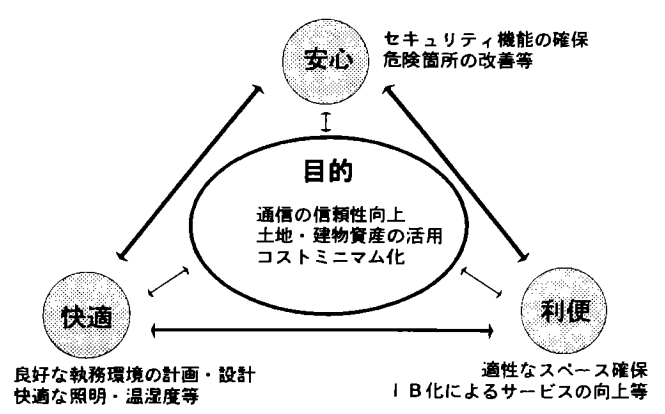

図 $3 \quad \mathrm{FM}$ の目的と付加価值

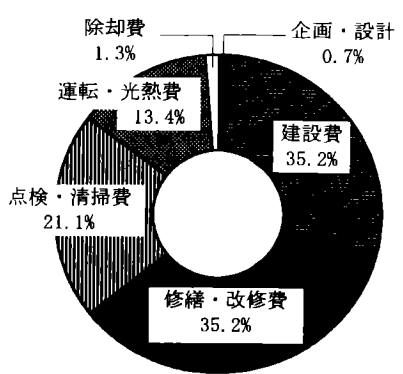

図 4 電気通信用建物のライフサイクルコスト構成

い資料作りが要請された。

これらのニーズを解決するため, それまでの社内における建築維 持保全に関わる研究開発の蓄積と改修・修繥工事の設計・監理経験, 外部の耐久性研究成果を統合して「建物劣化診断・整備提案システ ム」の開発を行うこととした。

\section{5 建物劣化診断・整備提案システムの概要}

(1) 概要

本システムの概要を図 5 に示す。主な技術的特徴は以下の通りで ある。

(1)「建物部位劣化進行」「整㣁工法」「整備工法単価」のデータベ 一スを持つ。また，データ入力に用いる画面上に劣化現象に応じ て診断すべき点検項目と各点検項目に対する評価基準を表示する 機能を有し, 診断担当者を支援する。

(2) 診断担当者が選定した診断すべき建物部位について, 劣化現 象・劣化の程度, 劣化数量の点検結果を入力することにより, 自 動的に劣化の評価を行い, 劣化レベルの計算, 劣化進行の予測を 行う。

(3) 建物の将来利用計画情報や劣化レベル，劣化数量をもとに建物 
部位ごとに要求される整備レベルを検討し，整備工法の選択，整 備実施による劣化の回復計算, 整備コストを計算する。

(4) 整備すべき主要な建物部位を選択することにより,上記の劣化 と整備の情報をもとにした整備計画提案書, 整備仕様書, 工事概 算書を作成する。

(5) 本システムが提供する各種情報により, 建物経営者が整備計画 提案書に示された建物部位の劣化状況, 整備時期, 整備投資と劣 化回復の突き合わせ情報により建物整備事業計画を検討出来るほ か, FM 担当者が建物劣化定期点検の実施や修綣 - 改修工事発注 の参考資料作成を効率的に行うことができる。

\section{(2) システムの構成}

(1) 診断建築部位：本システムは図 6 に例示するものを含めた 95 建築部位を対象としており，これら各建築部位とこれまでの電気 通信建物用建築工事仕様書の中で指定してきた仕上げ材料を組み 合わせた約 230 の診断建築部位を設定し, 点検情報入力のための 劣化評価シートを用意している。

(2) 劣化現象: 各診断建築部位に発生する劣化現象は図 7 に例示 すように一般的な劣化現象を想定しているが, 整備は建築部位別 に行うため軀体・下地・仕上げのような建築部位を構成する要素 と各要素に発生する劣化現象に重み付けを行い, 建築部位として の劣化現象を構成している。

(3) 劣化レベル：建物経営者の理解を容易にするため, 本システム では劣化評価値, 劣化レベルを設定している。劣化評価值は建築

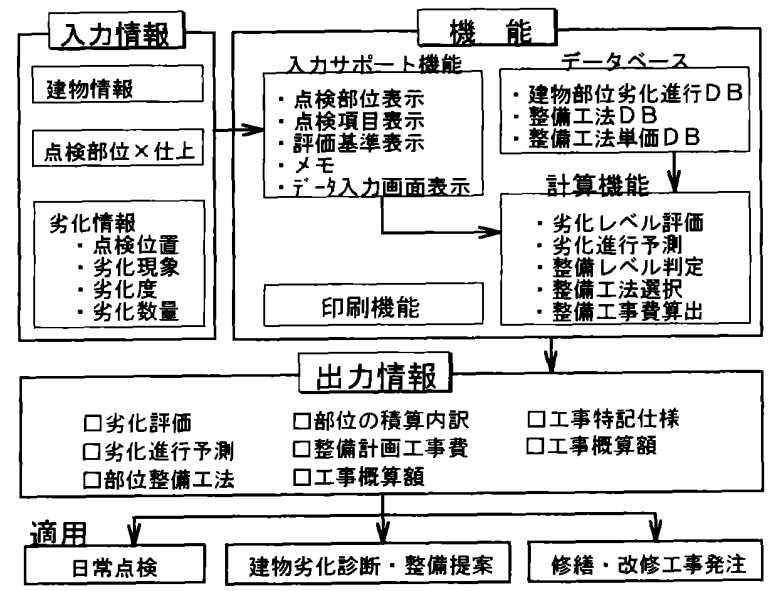

図 5 建物劣化診断・整備提案システムの構成

\begin{tabular}{|c|c|}
\hline 区建物外部 & \\
\hline ○屋上防水 & 押えアスファルト防水届、シート防水屏 \\
\hline & 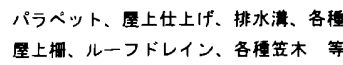 \\
\hline & $\begin{array}{l}\text { 各種吹付け仕上げ、タイル張り、金闽力 } \\
\text { ーテンウォール、シーリング 第 }\end{array}$ \\
\hline O外部建具 & 鋼製建具、アルミ建具＼cjkstart策 \\
\hline 建物内部 & \\
\hline O床 & 各糧床㤌上げ、改め蓋 等 \\
\hline O内 & 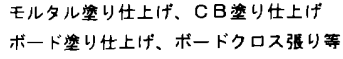 \\
\hline $\begin{array}{l}\text { O天 \# } \\
\text { O内部建具 }\end{array}$ & $\begin{array}{l}\text { 岩編吸音板杜上げ、システム天井 每 } \\
\text { 铜製建具 }\end{array}$ \\
\hline
\end{tabular}

図 6 診断建築部位例
部位としての劣化現象における重み付けを利用し, 建設当初時の 劣化評化值を 0 とし, その建築部位に期待される性能の劣化が限 界に達した時を 100 とした定量的表現である。また，この間を 4 分割した劣化レベルにより劣化の程度を定性的に表現している。 (4) 劣化進行予測：診断建築部位の各々について,これまで社内で 実施してきた建物材料・部位の耐久性調查, 改修・修繥工事の設 計・監理経験，社外の建築材料耐久性検討デー夕をもとに劣化進 行予測曲線を想定している。この予測曲線では建物が立地する環 境の影響を考慮し幅を持たせた劣化予測を行っている。また，こ の少化進行曲線をもとにして時間経過とともに劣化評価値も悪化 することとしている。

(5) 整備レベル：整備工法の選択の前処理として整備レベルを設 定している。整備レベルは劣化レベルと直接的に対応するもので はなく, 図 8 に示すよう耐用年数, 将来の建物利用計画等も合わ せて考慮されており, 整備レベルの確定によって, 建物用途計画 に応じた劣化の判断, 今後の整備工事への取組みの程度を整理し ている。

(6) 整備工法：整備工法もこれまで電気通信建物の整備工事で仕 様化してきたものを用意し, 各建築部位における各整備レベルに 応じ複数の整備工法をデータベースとして用意している。

(3) システムの利用

本システムを使用した作業フローを図 9 に示す。

(1) 劣化評価シート：現地調查では図 10 に示す劣化評価シート 画面を利用する。ここでは，各診断建築部位別に診断すべき劣化 現象と各劣化現象毎に 4 段階の評価基準が表示される。診断担当 者はこれらのガイドに従い, 劣化判定結果と劣化数量を入力する

\begin{tabular}{|c|c|c|c|}
\hline 部位 & 屋上（防水） & 外装タイル & 塗り・吹付け仕上 \\
\hline $\begin{array}{l}\text { 劣 } \\
\text { 化 } \\
\text { 現 } \\
\text { 象 }\end{array}$ & 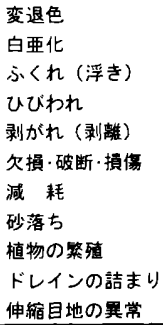 & 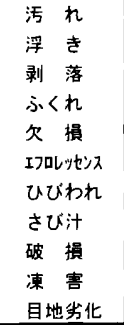 & $\begin{array}{l}\text { 污 れ } \\
\text { 変 色 } \\
\text { 退 色 } \\
\text { 白严化 } \\
\text { 減 耗 } \\
\text { ひびわれ } \\
\text { ふくれ (浮き) } \\
\text { 剥がれ(剥離) } \\
\text { さび }\end{array}$ \\
\hline
\end{tabular}

図 7 劣化現象例

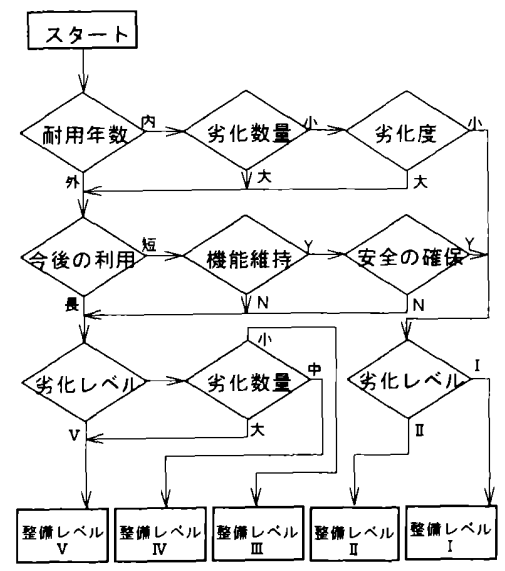

図 8 整備レベル判定フロー 


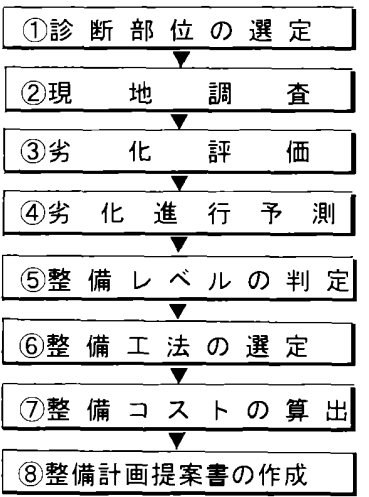

図 9 建物劣化診断・整備提案システムを利用した作業つロー

ことができる。また，データ入力に伴い劣化評価值が計算される ため，劣化状況を定量的に把握することも可能となる。

(2) 劣化進行シミュレーション: 劣化進行予測曲線画面では, 始め に診断時の建築部位の劣化評価值と劣化進行予測曲線が表示され るが，整備工法を選択することにより劣化進行予測曲線が整備終 了後の劣化評価位置に移動する。整備工法を自由に選択し直すこ とにより建物用途計画に応じた適切な整備工法の選択をシミュレ ートすることができる(図 11)。

(3) 整備コスト：整備コストの集計は診断した全建築部位につい て 2 つの将来時点を選択して行うことが出来る。整備コストの算 定を終えると, 劣化レベル・整備レベル・整備工法・整備コスト・ 費用区分を一覧することができる（図 12）。

(4) 整備計画：整備計画の検討は診断した建築部位の中から, 整備 を急ぐもの, 整備コストが大きいものなどを判断し, 主要 10 建築 部位を選択して行う。各建築部位について 2 つ時点での劣化回 復状況と整備コストの比較ができ, 整備投資とその効果について の判断材料を提供できる（図 13）。

建物経営者へは図 14 に示寸整備計画提案書が提出される。

（4） システムの導入効果

本システムを使用した 3 千 1 万 $\mathrm{m}^{2}$ 建物における 34 例の建物 劣化診断・整備提案業務の実施稼働分析を図 15～図 17 に示す。

(1) 実施状況：診断した建築部位数は建物規模との相関は低い, 診 断建築部位数（作成劣化評価シート数）は 5 〜約 55 枚に分布し, 平均で 28 建築部位/建物である。これは診断担当者が仕仕上げ種 類，建物経年，劣化状況等により診断建築部位を判断しているた めと考えられる。

(2) 必要稼働時間：診断建築部位当たりの稼働時間は診断建築部 位数が 10 程度以上となると，約 80 分/建築部位となる。

(3) 稼働構成：全稼働のうち, 図面・情報収集, 診断建築部位の面 積算出, 調査計画などの準備作業に稼働の約 $40 \%$ が, 現地調査に 約 16\%が，デー夕整理・積算に約 23\%が，提案書作成に約 $18 \%$ が使用されている。同程度の建物を本システムを使用せずに劣化 診断し, 整備提案を作成した場合に比べ, 現地調査, デー夕整理・ 積算，提案書作成作業を中心に稼働削減が達成されている。また， この分析は初回のシステム利用データであり，データベースが整 備されることにより診断建築部位の面積算出などの基礎的作業が 省略できるため, 2 回目以降のケースでは, 一層の稼働削減が期

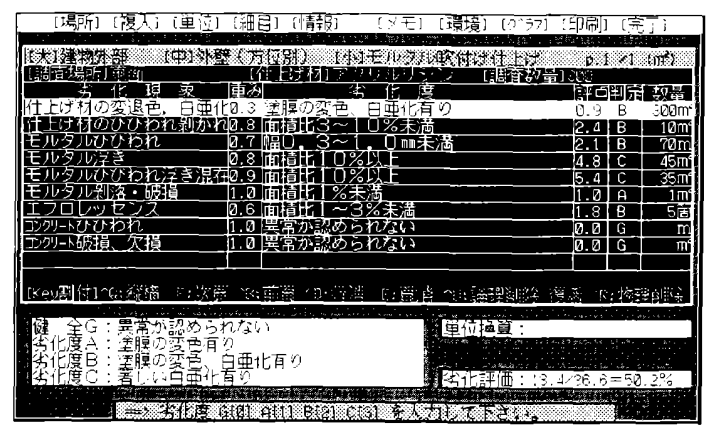

図 10 劣化評価シート画面

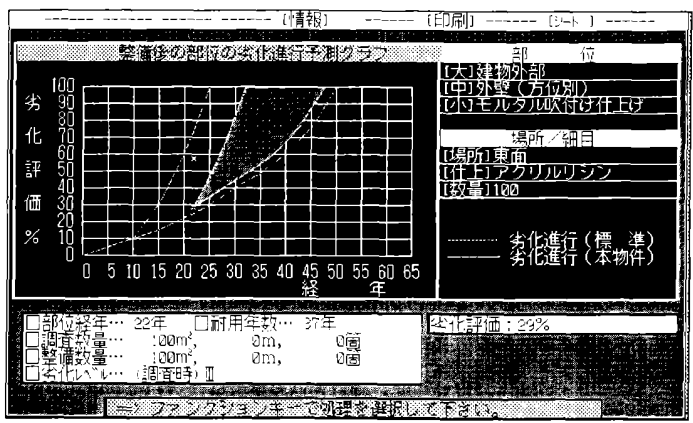

図 11 劣化進行予測曲線画面

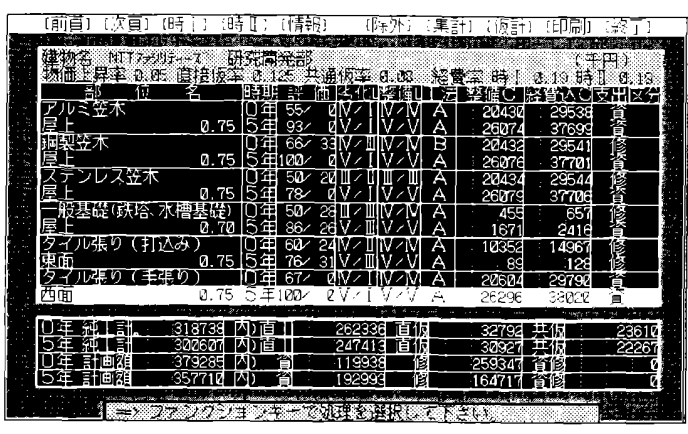

図 12 整備計画一覧画面

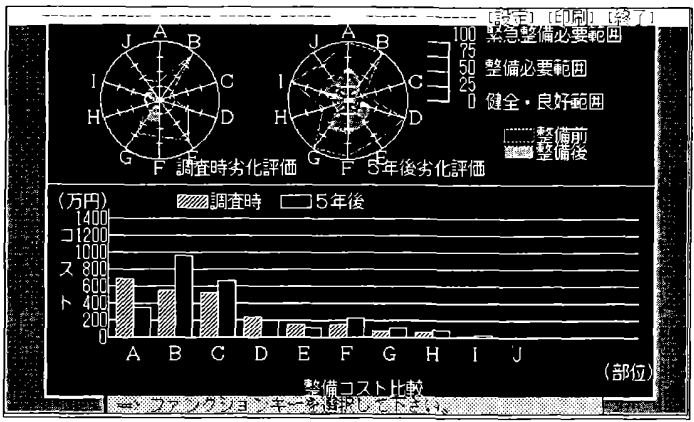

図 13 整備計画グラフ画面

待できる。

\section{6 おわりに}

既存建物ストックの利活用が叫ばれている。このためには, 建物 の現状を的確に把握し, 維持保全データベースを整備し, 中長期計 画のもとに建物更新を図ることが重要である。これは, 建築維持保 


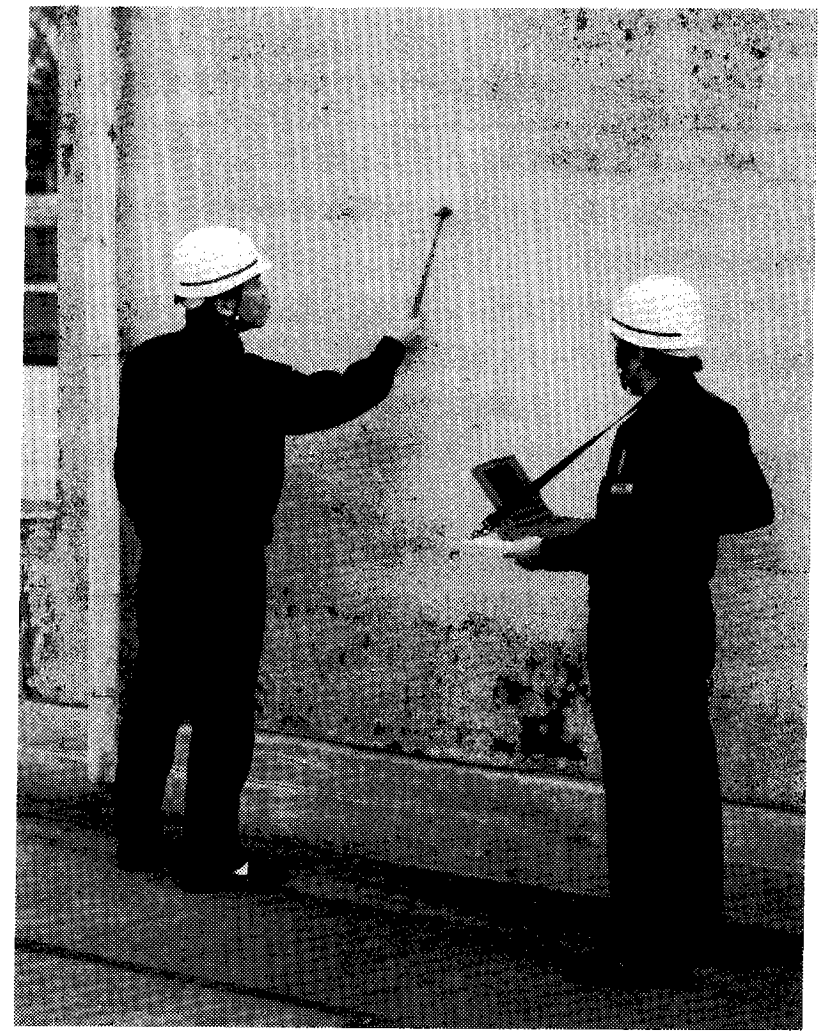

写 真

整備計画提案書作成例

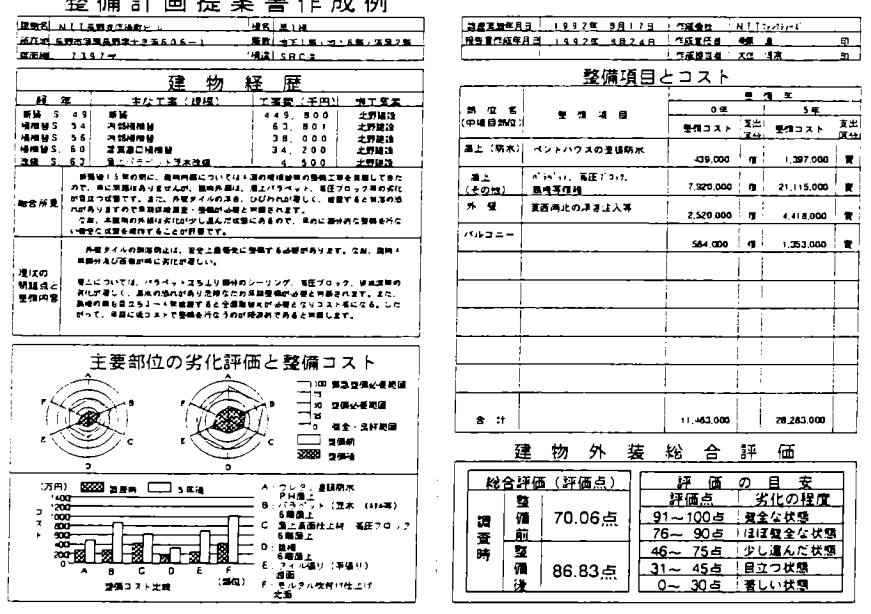

図 14 整備計画提案書例

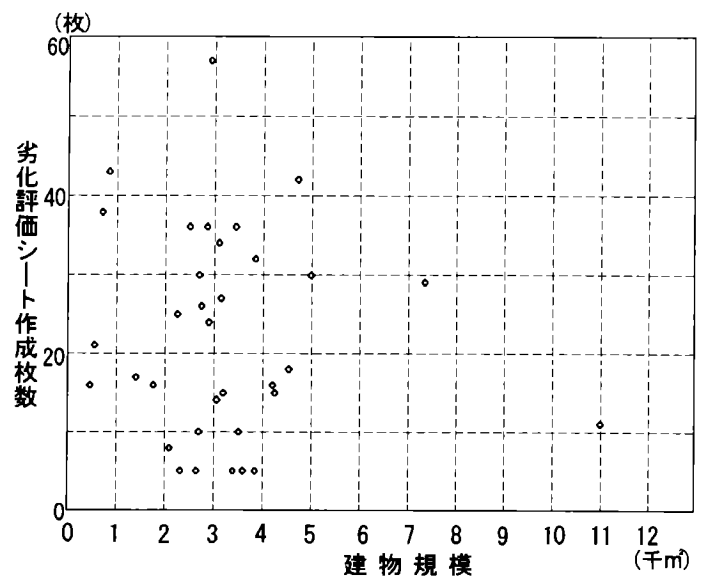

図 15 調査建物規模と劣化評価シート作成枚数

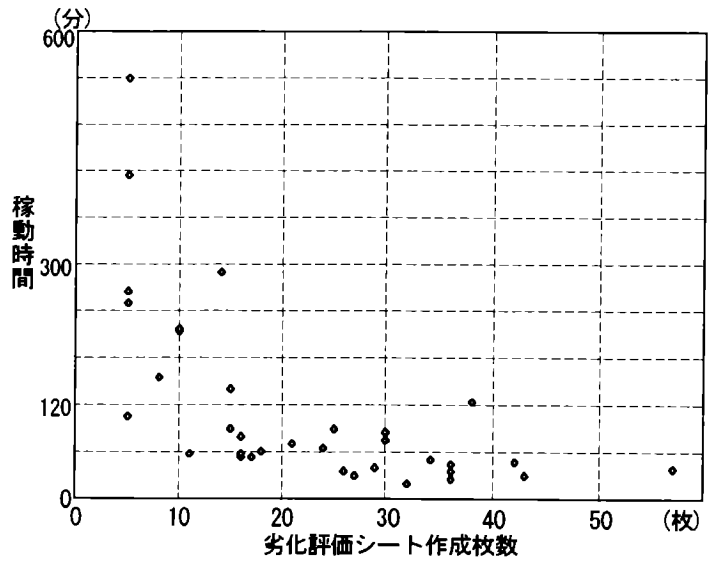

図 16 建物劣化診断・整備提案業務の実施時間
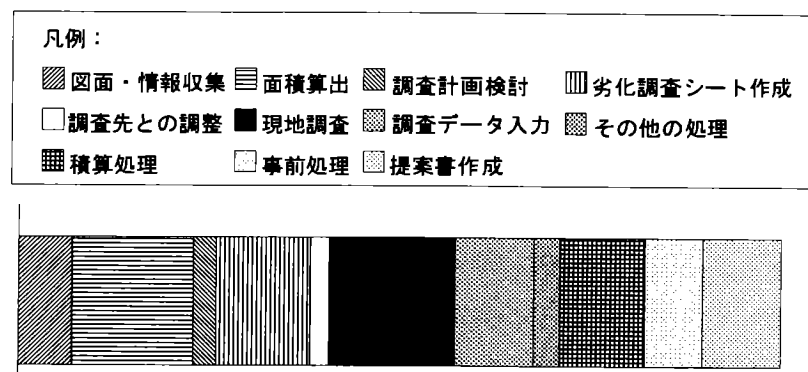

$\begin{array}{llllllllll}0 \% \quad 10 \% \quad 20 \% & 30 \% & 40 \% & 50 \% & 60 \% & 70 \% & 80 \% & 90 \% & 100 \%\end{array}$

図 17 建物劣化診断・整備提案業務の稼働構成

全業務が建築技術領域内のみに止まることなく, FM 的発想に立つ て経営へ参画すること，経営をサポートすることが要求されている ことを意味する。専門的な経験や知識, 蓄積された調査研究デー夕 を活用し, 建物部位構成や劣化現象など樣々な要因を総合的に取り まとめ, 建物経営者に対し信頼される技術力とデー夕の裏付けをも って整備工事への投資とその効果を判りやすく提案することが必要 である。

「建物劣化診断・整備提案システム」では, 永年にわたり培ってき た建築維持保全関連の調査研究データと設計・監理経験を総合し, 建物の劣化を診断 (CHECK) $\Rightarrow$ 計画 (PLAN) $\Rightarrow$ 整備 (DO) とい ったサイクルで捉え, 劣化診断から建物整備計画までを一連のシス テムとしてまとめている。そして, 本システムの導入により建物の 維持保全業務では効率化とレベル確保が達成されており, また, 建 物経営者に対し管理建物の劣化状況と整備時期・整碏投資について の情報を提供でき, 的確な経営判断のサポートが可能となっている。

\section{参考文献}

1）桑原 滋, 山下武則, 大住博宗：建物劣化診断・整備提案システ ムの概要, 日本建築学会第 16 回情報システム利用技術シンポジ ウム予稿集, pp. 527〜 532, 1993

2）飯塚 裕：建築維持保全, 丸善, 1990

[1995 年 6 月 30 日原稿受理 1995 年 8 月 25 日採用決定］ 